\title{
Religious traditions in modern South Asia: London and New York: Routledge, 2011. xvi + 348 pages
}

\author{
Arvind Sharma
}

Correspondence: arvind.sharma@mcgill.ca Birks Professor of Comparative Religion at McGill University, Montreal, Québec, Canada
One way of summarizing the contents of this book would be to say that it identifies a paradox involved in claiming that south Asia, as a region, contains distinct religions on the one hand, and also claiming, on the other, that it is "a region of great religious diversity" (1), for religion diversity could compromise the claim to religious distinctness on the part of its various religions. After identifying this paradox, the book explores it in detail with a wealth of historical and anthropological evidence. Yet another way of summarizing the contents of this book would be to say that it examines the religious traditions of south Asia phenomenologically in part one of the book and historically in part two. Part one of the book investigates themes which cut across various religious traditions, such as those of deity, texts and their authority, myth, ritual, teachers and their traditions, and caste (instead of focusing on the various religious traditions individually) while part two focuses on how these individual religious traditions have been shaped by the historical processes set in motion by their encounter with the modern West. Yet another way of describing the contents of this book would be to say that it questions the application of the World Religions model of studying religion, in which the various religions found in south Asia, such as Hinduism, Buddhism, Jainism, Sikhism, Zoroastrianism, Judaism, Christianity, Islam, and Baha'i "are treated separately in different chapters" (xii; also see 251), by interrogating these categories critically. Yet another way of summarizing the contents of this book would be to say it presents the various religious traditions of south Asia at the points of intersection between tradition and modernity. Yet another way of summarizing the contents of this book would be to say that it highlights the problems of applying the Western word "religion", with its underlying assumption of exclusive religious identity, to the religious reality of south Asia, where dual or multiple religious identity is not an unusual phenomenon.

That the contents of a book could be summarized in so many ways with equal plausibility-this fungibility as it were-testifies to its richness of content. It is the best book I know which does not merely assert the porousness of the boundaries of the various religions of south Asia, but also investigates this phenomenon with a variety of methods known to the study of religion, such as the historical, the phenomenological, and the anthropological. It also possesses a further merit. Such porousness has been usually acknowledged in relation to the religious traditions which originated in south Asia, namely Hinduism, Buddhism, Jainism, and Sikhism, which are often collectively 
referred to as constituting the Indic religious tradition. This book also demonstrates how Christianity and Islam in south Asia also often shared this permeability.

This book of many merits, however, is not free from some shortcomings; hardly any book is. It gives the date of the composition of the Ramcharitmanas of Tulsidas unfortunately as 15743 (81). Similarly, while it correctly states that Books 1 and 7 of Valmiki's Ramayana are considered to be later additions by most scholars, it might have been worth noting that some scholars, like Alf Hiltebeitel, prefer to explain the distinctness of these Books theologically rather than chronologically. More seriously, it states without qualification that "the varna system does not include the so-called untouchable castes" (145). Similarly, the claim that "individual reading" of Vedic texts was "entirely alien" (55) in Hinduism needs to be reconciled with the fact that each individual of the three higher varnas is called upon to study the texts (Kane 1974: 700) and that according to Skanda-Maheśvara (c. eighth century) all the mantras of the Vedas may be applied to all the philosophical systems (Murty 1993: 67 note 30), and they were (Kane 1977: 1218). The very fact that there are several schools and sub-schools of the systems of Vedānta (Mahadevan 1971: VII) implies that some individuals did indeed offer their own readings distinct from those received traditionally.

Some of these issues however are staples of modern Indology as such, which need to be addressed, and cannot in fairness be laid at the door of the authors, who have produced a refreshingly original book which breaks new ground in many ways.

Competing interests

The author declare that he has no competing interest.

Received: 12 May 2015 Accepted: 16 June 2015

Published online: 02 July 2015

References

Kane, PV. 1974. History of Dharmaśāstra (Ancient and Medieval Religious and Civil Law in India), vol. 2, Part 1. Poona: Bhandarkar Oriental Research Institute.

Kane, PV. 1977. History of Dharmaśāstra (Ancient and Medieval Religious and Civil), vol. V, Part 2. Poona: Bhandarkar Oriental Research Institute.

Mahadevan, TMP. 1971. Outlines of Hinduism. Bombay: Chetana Limited.

Murty, K, and Satchidananda. 1993. Vedic Hermeneutics. New Delhi: Motilal Banarsidass.

\section{Submit your manuscript to a SpringerOpen ${ }^{\circ}$} journal and benefit from:

- Convenient online submission

- Rigorous peer review

- Immediate publication on acceptance

- Open access: articles freely available online

- High visibility within the field

- Retaining the copyright to your article

Submit your next manuscript at $>$ springeropen.com 